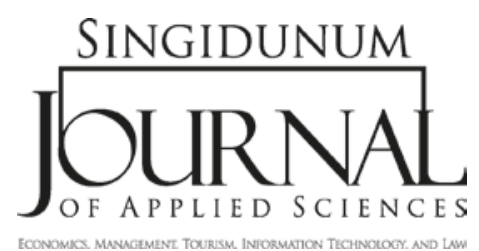

SJAS 2014, 11 (2): 20-29

ISSN 2217-8090

UDK: 659.127 ; 005.511:339.138(520+540)

DOI: $10.5937 /$ SJAS11-5504

Original paper/Originalni naučni rad

\title{
QR CODE BASED MARKETING IN INDIA AND JAPAN
}

\section{Hemant Bamoriya*}

Acropolis Faculty of Management and Research

Indore Bypass Road, Indore, India

\begin{abstract}
:
Despite the colossal growth of Quick Response Codes (QR codes) in marketing, many critics are worried about effective integration of QR code in marketing mix. The reason is the lack of knowledge about consumers' beliefs and intentions towards QR codes. Substantial variations in exposure and adoption rate of QR code across cultures further deteriorate the application of QR code in marketing. This study intends to explore consumers' beliefs and intentions towards QR codes in marketing across different cultures, namely India and Japan. The study also intends to analyze how the selected variables moderate the relationship between beliefs and intentions. A scenario-based experimental design was used and data was analyzed using Structural Equation Modeling and General Linear Modeling. The findings suggest a positive relationship between culture and beliefs as well as between beliefs and intentions. Further on, media and on-campaign instructions are found to be significantly moderating the relationship between beliefs and intentions. Finally, based on the key findings, the study offers some valuable perspectives on the evolving nature of QR codes in marketing and provides implications for marketers.
\end{abstract}

\section{Key words:}

advertising,

culture,

mobile marketing,

QR code.

\section{INTRODUCTION}

\section{Background}

Marketers have a growing interest in mobile phones as a marketing channel (Wohlfahrt, 2002). Quick Response code (QR code) is one of the most innovative modes of mobile marketing. $Q R$ code is a 2D code which once scanned using Smartphone -with a scanning application software like ScanLife, i-nigma and an active Internet connection-connects the user to some specific online content (e.g. a webpage), delivering e-coupons etc. (Bisel, 2011). Denso-Wave (Japan) was the first one to use QR code back in 1994, for quick and convenient tracking of the inventory. Later on, marketers became aware of $\mathrm{QR}$ code functionalities i.e. its benefits in usage - they realized that QR code functions could be transferable to marketing domain i.e. that they offered the potential to connect easily and swiftly with customers on-the-go (the quick part of QR code) and encourage customer engagement (the response part of QR code). 


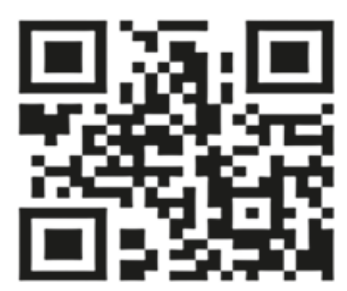

Figure 1: Sample QR code

QR code offers plenty of advantages to marketers due to its immense technological capabilities. QR codes are open as Denso-Wave (developer of QR code) did not patent them. Thus, it is easier for both marketers and mobile users to get the tools for generating, scanning or decoding of the $\mathrm{QR}$ codes.

QR code is omnidirectional and scannable, which means that unlike barcodes, it can be scanned from any angle, thus providing further consumer facilitation. QR codes also offer great versatility to marketers as they can be enlarged to the size of a billboard or minimized to the size of a stamp. Even these black and white codes can easily be transformed to "designer" QR code by adding colors and putting brand name or logo in the forefront of the code image (Podfigurny, 2011). Furthermore, QR code enables marketers to track the number of scans on each code and identify the source medium of the scan. This is certainly very helpful to marketers in measuring consumer activity at the micro level. Finally, at their best, QR codes can bridge the online and offline worlds as a QR code offers the possibility of integrating online (e.g.on a website) and offline content (e.g. a newspaper ad). Thus, QR code enables markets to exercise creative multichannel marketing (Tolliver-Walker, 2011). For consumers, it means offering an exciting avenue of interactivity, engagement and exploration (Bisel, 2011). All of the above-mentioned indicates that the QR code can become the central core of tremendous customer engagement tools.

Nowadays, the usage and analysis of QR codes has become one of the most widespread marketing trends, especially in Japan, the USA and Western Europe. Furthermore, with the adoption of Smartphones, the popularity of QR code is rapidly increasing across Asia, in particular in India, Korea, and Indonesia. During the period from January 2010 - January 2011, QR code scans increased worldwide by a whooping rate of 45-49\%. Moreover, 11 out of 50 Fortune companies ${ }^{1}$ incorporated QR codes into

1 The Fortune 500 is an annual list compiled and published by Fortune magazine that ranks the top 500 U.S. closely held and public corporations as ranked by their gross revenue. their marketing strategy. Undoubtedly, enormous growth has been observed worldwide over the last 2-3 years, in both QR code usage and scan (Daniells, 2011; Tolliver-Walker, 2011). Many critics think that though QR code itself is a very powerful and cost effective tool, the marketers are not clearly focused on its added value, thus failing to drive customer engagement through QR codes (Podfigurny, 2011). That could be the result of insufficient knowledge about consumers' beliefs and intentions towards QR codes.

\section{Scope of the Study}

Several previous studies (e.g. Probst, 2012; Okazaki et al., 2012) preliminary explored the use of QR codes in marketing. However, they just focused on the part which refers to consumers' perceptions. Also, the focus of their attention was only on developed countries (USA and Japan respectively); whereas there has been practically no research on developing countries such as India. This study focuses on in-depth exploration of consumers' beliefs and intentions towards the use of QR codes in marketing. The study further attempts to examine the phenomenon across cultures such as India and Japan. The influence of culture on consumers' beliefs and attitudes towards marketing promotion is well documented in the literature (Durvasula and Lysonski, 2013; Ko et al., 2005; La Ferle et al., 2008; Wang and Sun, 2010a; Wang and Sun, 2010b; Mooij, 2011). India and Japan are the two countries selected for cross-cultural comparison because they both have entirely different cultural orientation (Hofstede et al., 2010). These differences render a meaningful comparison to examine the impact of culture on QR code marketing. As Japan has a high $40 \%$ penetration of Smartphones - which are the basic devices for code scanning- it enjoys most QR code scans (Daniells, 2011). On the other hand, Smartphone penetration in India is low and Smartphones constitute only approximately $8 \%$ of the total number of mobile phones in the country. Furthermore, India has only $1.8 \%$ of total global QR codes in terms of country of origin. However, it is witnessing rapid diffusion of mobile Internet and Smartphones (Daniells, 2011), so it is sensible to analyze QR code marketing in India along with Japan. At last, the study tries to investigate the effects of the moderating role of the selected variables on the relationship between culture and consumers' beliefs. 


\section{LITERATURE REVIEW}

\section{The relationship between beliefs and behavioral intentions}

In psychology, intentions of an individual are supposed to capture motivational factors that influence a particular behavior. Many authors tag individual's intention to be the outcome of his/her set of beliefs (Wu and Wang, 2005). As a general rule, an individual generates beliefs about an object by associating it with certain attributes and ultimately links it with particular intention. According to Wang and Sun (2010a), such beliefs are considered to be the prevailing determinants of an individual's intentions.

In a similar manner, various authors report consumers' beliefs about marketing promotions - both offline and online media, to be one of the determinant factors of consumers' intentions towards advertising (Patnaik and Patnaik, 2005; Hanafizadeh and Behboudi, 2012; Tsang-Sing et al., 2004; Karson et al., 2006; Bamba and Barnes, 2006; Chun and Wan, 2009; Mafe' et al., 2010; Wang and Sun, 2010a; Bamoriya and Singh, 2012). In the context of mobile marketing, Bamoriya and Singh (2012) empirically reported that consumers' beliefs about mobile marketing influence their intentions in terms of receiving SMS ads. Similarly, Mafe' et al. (2010) explored the consumers' beliefs towards SMS mediated promotions. They reported that consumers' beliefs strongly influence their intentions to respond to mobile promotion. As QR codes are one of the modes of mobile marketing, this study assumes that consumers' beliefs about QR codes are positively associated with their intentions. Thus, it is suggested to follow the below given directional hypothesis:

H1- The stronger positive beliefs towards QR codes in marketing, the more likely one will intend to scan a QR code.

\section{Culture, beliefs and marketing promotions}

According to Hofstede et al. (2010), an individual's set of beliefs can be tied into five cultural dimensions - individualism/collectivism, power/distance, uncertainty/avoidance, masculinity/femininity and long-term/short-term orientation. Index values of all these dimensions vary across cultures, as reflected in Table 1 for India and Japan (indicating cultural differences between these two countries). Mooij (2011) intensively studied the application of the Hofstede's cultural dimensions in international marketing con- text and reported that different sets of beliefs towards marketing promotion prevail due to cultural differences (significantly different index values).

\begin{tabular}{lcc}
\hline Dimension & India & Japan \\
\hline Individualism & 48 & 46 \\
\hline Power_Distance & 71 & 54 \\
\hline Uncertainty_Avoidance & 56 & 92 \\
\hline Masculinity & 56 & 95 \\
\hline Long-term_Orientation & 61 & 80 \\
\hline
\end{tabular}

Table 1: Cultural dimensions - Index values

Source: Hofstede (2010)

The relationship between culture and beliefs towards marketing promotions is well-researched and documented (Ko et al., 2005; Durvasula and Lysonski, 2013; Mojsa and Rettie, 2003; Al-Juhiam 2008; La Ferle et al., 2008; Usman et al., 2010; Wang and Sun, 2010a; Wang and Sun, 2010b). In general, findings from previous studies suggest that beliefs towards marketing promotions vary across cultures; thus these variables should be intrinsically linked. Furthermore, with rapid globalization marketers are becoming more interested in cross-cultural studies in various business domains including mobile marketing and the use of QR codes within it. Insights from such studies would enable them to understand culturally diverse markets and respond accordingly. Hence, it will be of vital importance to examine beliefs about QR codes in marketing across cultures. However, due to practically non-existence of research on comparing QR codes in marketing between India and Japan or any other country, it would be premature to predict how culture influences these two variables. Hence, it is proposed to follow the non-directional hypothesis:

H2 - Culture will influence individual's beliefs towards QR codes in marketing.

\section{Variables moderating the relationship between beliefs and intentions}

Preliminary findings of focus group study of Okazaki et al. (2012) hint that the location of the customer where s/he would encounter QR code (e.g. home or bus stop) and the type of media used (say magazine or billboard) may influence customer's intention to scan a QR code. Nevertheless, there is no explicit academic literature on the variables which might moderate the relationship between beliefs towards QR codes in 
marketing and subsequent intentions. Apart from media and location, there could be other possible moderators affecting the above-mentioned relationship between beliefs and behavioral intentions. Thus, a couple of informational interviews were held with a range of subject matter experts to explore the area. The majority of the interviewed experts strongly reckon that media and location should moderate the relationship between beliefs and intentions in the context of QR

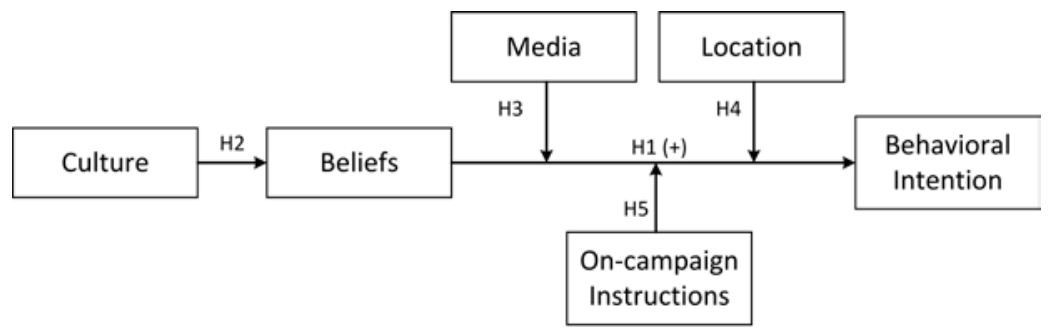

Figure 2: Conceptual model codes in marketing, thus adding validity to the findings of the qualita-

\section{Design}

tive study by Okazaki et al. (2012). Furthermore, the majority thinks that on-campaign instructions may be very critical in driving the desired behaviour, as general awareness about QR code is still not very high. The online marketing survey conducted by the market research firm "Simpson Carpenter" supports this argument; the results of the survey indicate that only $36 \%$ of consumers know what a QR code is and how to scan it (Charlton, 2011). Hence, based on the above-given views and studies, the following nondirectional hypotheses are proposed:

H3 - Type of media used will moderate the relationship between beliefs towards QR codes in marketing and intention to scan $\mathrm{QR}$ codes.

H4 - Customer location will moderate the relationship between beliefs towards QR codes in marketing and intention to scan $\mathrm{QR}$ codes.

H5 - On-campaign instructions will moderate the positive relationship between beliefs towards QR codes in marketing and intention to scan QR codes.

\section{RESEARCH METHODOLOGY}

\section{Research framework}

Figure 2 presents the conceptual model underlying this study. The model assumes that culture influences beliefs towards using QR codes in marketing. In addition, these beliefs influence intention to scan QR code. This relationship between beliefs and intentions is moderated by variables-media, location and on-campaign instructions.

For the purpose of this study, a multi-channel attribution modeling ( 3 (media) by 2 (location) by 2 (on-campaign instructions) 'scenario based experimental design') was used to test the hypotheses (see Table 2). The selected media types were - magazine (coded as 3 ), product packaging (coded as 2 ) and pamphlet (coded as 1). Similarly, home (coded as 2) and shopping malls (coded as 1) were selected as the location where customer will encounter a QR code. 'On-campaign instructions' variable was chosen as dichotomous; with instructions (coded as 2) - a scenario where marketing communication explicitly specifies how to scan QR code, where to find application and what to expect after a scan, and without instructions (coded as 1$)$. These twelve scenarios $(3 \times 2 \times 2)$ were intended to be administered across cultures, where Indian culture was coded as 1 and Japanese culture as 2 .

A hypothetical person (Mr. Z) was used in all of the above-mentioned scenarios to discourage social desirability effects. Hence, a narration of each scenario was prepared describing location (home/shopping mall) of Mr. Z and media (newspaper/product packaging) on which QR code is placed. In six scenarios with on-campaign instructions, adjacent to the QR code, some clear instructions were placed regarding what Mr. Z should do to get a code reader, how to scan the code and what would be there for Mr. Z if he scans the code. Nonetheless, QR code had no such instructions in remaining scenarios i.e. without oncampaign instructions. All scenarios included a visual representation of a QR code along with narration. Subsequently, each scenario was subject to pretest using convenience sampling to gauge clarity of the scenario and determine face validity. Based on the total of 33 responses, minor rewriting was done in two open-ended questions, and scenarios were finalized. 


\begin{tabular}{cccc}
\hline Media & Location & On-campaign Instructions (OCl) & Scenario \\
\hline Magazine & Home & With OCl & 1 \\
\hline Magazine & Home & Without OCl & 2 \\
\hline Magazine & Shopping Mall & With OCl & 3 \\
\hline Magazine & Shopping Mall & Without OCl & 5 \\
\hline Product Packaging & Home & With OCl & 6 \\
\hline Product Packaging & Home & Without OCl OCl & 7 \\
\hline Product Packaging & Shopping Mall & Without OCl & 8 \\
\hline Product Packaging & Shopping Mall & With OCl & 9 \\
\hline Pamphlet & Home & Without OCl & 10 \\
\hline Pamphlet & Home & With OCl & 11 \\
\hline Pamphlet & Shopping Mall & Without OCl & 12
\end{tabular}

Table 2: Study's experimental scenarios

\section{Scale}

Beliefs about QR codes in marketing were measured prior to administrating scenario based experimental study. In order to measure it, a 4-item five point semantic differential scale (worthless/valuable, unnecessary/necessary, unimportant/important and insincere/sincere) was adopted from Durvasula and Lysonski (2013). Cronbach's alpha values were also exceeding recommended value of 0.7 for both Indian (.84) and Japanese samples (.88). Intention towards QR code in marketing was measured after administrating scenario-based experimental study. It was conceptualized as intention to scan QR code and was measured on a five-point scale; 1 for 'very unlikely' to 5 for 'very likely'.

\section{Sampling and data collection}

A purposive sampling (unit of analysis; college students) was executed at one Indian and one Japanese university, on the basis of 3 screening questions. Namely, 289 questionnaires were collected in India and 297 in Japan. After discarding the data from

\begin{tabular}{ccccc}
\hline Male & Female & $\begin{array}{c}\text { Average history of } \\
\text { Mobile Internet } \\
\text { Usages }\end{array}$ & $\begin{array}{c}\text { Average reported } \\
\text { exposure of QR } \\
\text { Codes }\end{array}$ \\
\hline Japan & $57.3 \%$ & $42.7 \%$ & 6.7 years & 3.24 years \\
\hline India & $63.3 \%$ & $34.6 \%$ & 2.5 years & 1.95 years \\
\hline
\end{tabular}

Total Valid $\mathrm{N}=574$

Table 3: Sample profile the missing values and outliers, a total of 574 usable questionnaires ( 3 outliers in Indian sample and 9 outliers in Japanese sample detected by computing $\mathrm{Z}$ scores) were available for analysis.

\section{Scenario-administration}

Groups of about 20+ respondents from Indian and Japanese samples were randomly assigned to one of the twelve experimental scenarios. Appropriate coding was done for all variables. Respondents were asked to read the written scenario and answer the questionnaire to measure their intention towards QR code in marketing.

\section{ANALYSIS}

\section{Linear effect analysis}

Structural equation modeling (SEM) using AMOS18 was performed to assess the proposed model fit and test the hypotheses. In order to test the hypotheses $\mathrm{H} 1$ and $\mathrm{H} 2$, a SEM was first conducted without moderating effect of media, location and on-campaign instructions (seeFigure3). The results indicated a good model fit with $\chi 2(11)=17.01 ; p>.001$; $\chi 2 / d f=1.546$; Goodness of Fit Index $=.917$ and, a significant improvement over null model with Comparative Fit Index = .921; Tucker Lewis Index $=.912$.

The findings suggested that the relationship established/given in the 


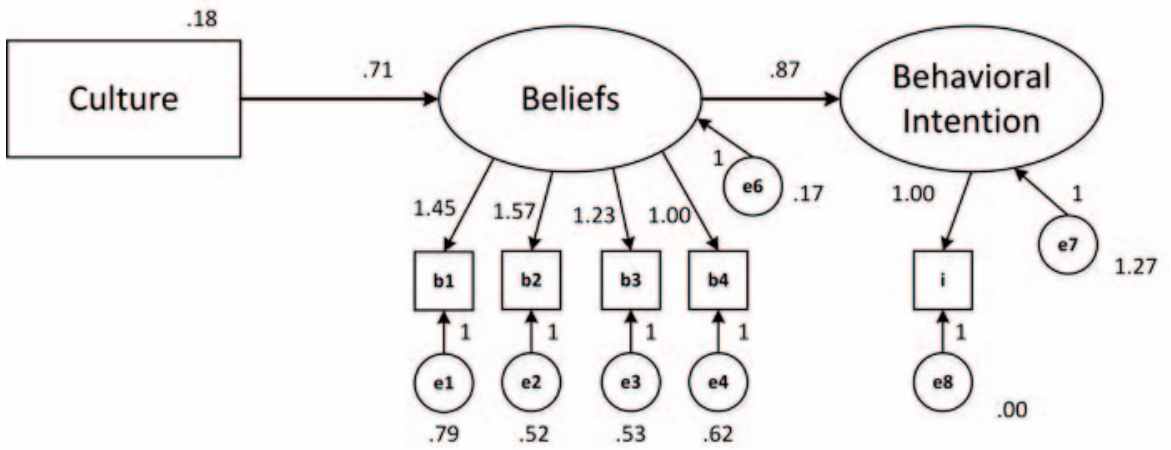

Figure 3: Structural model without moderating effects

hypotheses between culture and beliefs (regression weight $=.709 ; \mathrm{p}<.05)$ and beliefs and intention (regression weight $=.868 ; \mathrm{p}<.01)$ are significant. Hence, hypothesis $\mathrm{H} 2$ that "Culture will influence individual's beliefs towards QR codes in marketing" is accepted. Similarly, hypothesis $\mathrm{H} 1$ - "The stronger positive beliefs towards QR codes in marketing, the more likely one will intend to scan a QR code"is accepted.

\section{Moderating effect analysis}

General Linear Model (GLM) mono-variant analysis was performed to estimate moderating effects of media, location and on-campaign instructions on the relationship between beliefs towards QR codes in marketing and intention. Intention (i) was dependent variable while composite scores (scores calculated by

\begin{tabular}{lccc}
\hline \multicolumn{1}{c}{ Effect } & Mean Square & $\mathrm{F}$ & $\mathrm{P}$ \\
\hline GLM Analysis 1 & & & \\
Beliefs (b) & .889 & .599 & $.009^{* *}$ \\
Media (m) & .581 & .401 & $.032^{*}$ \\
Interaction (b*m) & .161 & .097 & $.000^{* * *}$ \\
\hline GLM Analysis 2 & & & \\
Beliefs (b) & .791 & .511 & $.041^{*}$ \\
Location (I) & 1.105 & .910 & .093 (n.s.) \\
Interaction (b*I) & .333 & .291 & .298 (n.s.) \\
\hline GLM Analysis 3 & & & \\
Beliefs (b) & .809 & .606 & $.007^{* *}$ \\
On-campaign inst.(o) & .621 & .484 & $.036^{*}$ \\
Interaction (b*o) & 1.77 & .109 & $.001^{* *}$ \\
\hline
\end{tabular}

Note: *Significant at .05, **Significant at .01, ***Significant at .001 level

Table 4: GLM Analysis Output averaging scores of the subscale items that belonged to the construct) for beliefs about QR code in marketing were a fixed factor (b). First, moderating variable media $(\mathrm{m})$ was selected as covariate and estimated for the effects of beliefs (b), media (m) and interaction $\left(b^{\star} m\right)$ on intention (i). Subsequently, the same procedure was performed for reaming two moderating variables namely location (l) and on-campaign instructions (o) (see Table 4).

The findings of GLM mono-variant analysis suggested that, in case of influence on intention, interactions between beliefs and media (.097, $\mathrm{p}<.001$; GLM Analysis 1) and as well as between beliefs and on-campaign instructions (.109, $\mathrm{p}<.01$; GLM Analysis 3 ) were significant. However, the interaction between beliefs and location (.291, $\mathrm{p}=.298$; GLM Analysis 2) was not significant. Hence, the hypothesis $\mathrm{H} 3$ - "Type of media used will moderate the relationship between beliefs towards QR codes in marketing and intention to scan QR codes" and H5 - "On-campaign instructions will moderate the positive relationship between beliefs towards QR codes in marketing and intention to scan QR codes" are accepted. However, hypothesis H4 that "Customer location will moderate the relationship between beliefs towards QR codes in marketing and intention to scan QR codes" is rejected. Hence, based on the findings of both SEM and GLM analysis, the following model was retained: 


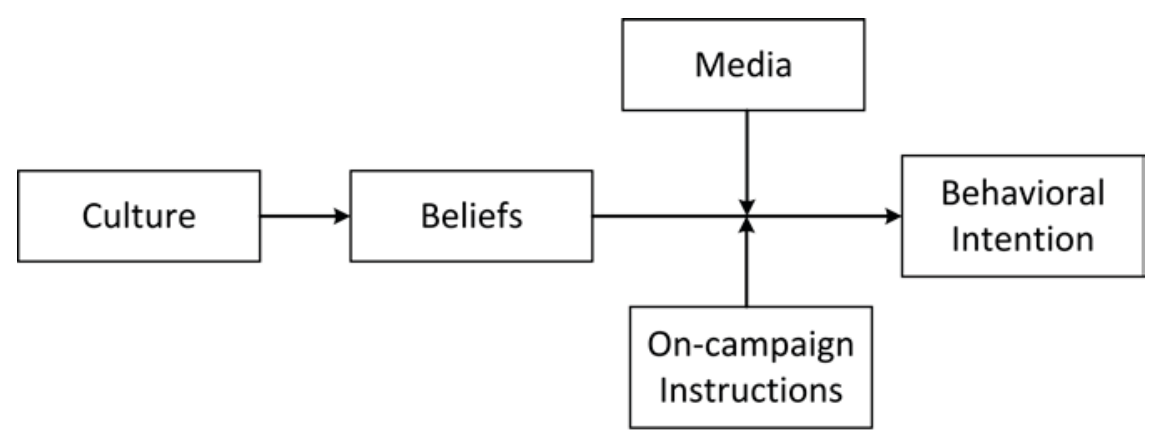

Figure 4: Retained model

\section{RESULTS AND DISCUSSION}

Preliminary analysis suggests that Japan is ahead of India in terms of the average hours of mobile internet usages. Also, Japanese have higher level of exposure to QR codes as a marketing tool compared to India. The reason could be attributed to the fact that Japan is the origin of QR codes. Higher penetration level of Smartphones in Japan could be another plausible reason. Aggregately, self-reported level of exposure to QR codes is low (especially in India), so marketers should focus on educating consumers about QR codes and their purpose, rather than simply adding QR codes to their marketing campaigns.

SEM analysis suggests that consumers' beliefs towards QR codes in marketing positively influence their intentions. This study is compliant with the previous studies in related areas such as online advertising (Patnaik and Patnaik, 2005; Hanafizadeh and Behboudi, 2012; Karson et al., 2006; Wang and Sun, 2010a) and mobile marketing (Bamba and Barnes, 2006; Bamoriya and Singh, 2012). It suggests that the consumers with positive sets of beliefs (in terms of necessary, valuable, important and sincere) towards the use of QR codes in marketing are very likely to scan a QR code. This is an important implication for marketers. First, if marketers want a positive response from consumers, then their QR code marketing promotion should be well planned. It means that marketers looking to implement QR codes into their overall strategies should define their goals and objectives in a crystal clear manner. Otherwise, it would give an impression of an unnecessary promotional effort from marketer's side, merely following the current trend. Second, marketers must provide some real value to customers once they scan a QR code. Here, an emphasis is placed on consumer experience and value addition after the scan will be a critical element in campaign effectiveness. For the purpose of value creation, marketers should utilize tracking capabilities of QR codes with due permission of consumers to generate relevant metadata. Third, QR code marketing promotion must avoid any insincere approach which may lead to consumers' frustration.

SEM analysis further suggests a positive link between culture and beliefs. This key finding is consistent with the past relatable studies (Ko et al., 2005; Durvasula and Lysonski, 2013; Mojsa and Rettie, 2003; La Ferle et al., 2008; Wang and Sun, 2010a; Mooij, 2011). In the context of using QR codes in marketing, Japanese respondents have more positive beliefs towards QR codes. Furthermore, Japanese respondents reported higher intention to scan a $Q R$ code used in marketing. The hierarchy of effect theory suggests that a belief is likely to have a positive impact on intention. Obviously, Japanese respondents' positive beliefs further led to higher intentions towards $\mathrm{QR}$ code marketing. These findings can be attributed to the cultural differences (significantly different index values for Hofstede's dimensions) between India and Japan. Especially, the two countries differ in terms of uncertainty avoidance dimension which is particularly relevant to innovative marketing practices (see Table 1). This is another important implication for marketers, who need to be aware of such cultural differences when employing a centralized mobile marketing approach using QR codes.

GLM mono-variant analysis suggests that the type of media used for QR code marketing moderates the relationship between beliefs and intentions towards QR code in marketing. This finding is consistent with qualitative findings of Okazaki et al. (2012). Three types of media were used in the study - magazine, product packaging and pamphlet - to form different scenarios. Magazine was found to be associated 
with more favorable behavioral intention to scan QR Codes while pamphlet with the least favorable behavioral intention. The reason could be nobility and credibility associated with magazines as a marketing media (Kiousis, 2001). Similarly 'on-campaign instructions' variable has moderating effect on the relationship between beliefs and intentions. These findings are consistent with Daniells (2011) reporting that a QR code based promotion offering clear instructions can drive consumer's scans up by 500 to $800 \%$. The reason may be that the use of QR codes in marketing is new and consumers are still not fully aware of them (Tolliver-Walker, 2011). This is an important implication for marketers to focus on increasing consumers' awareness level regarding $Q R$ codes so as to lead easy diffusion of QR codes.

\section{CONCLUSION}

In Japan, QR codes are widely used in marketing whereas there has been a gradual rise in their usage in India. This study attempted to explore the relationship between consumers' beliefs and intentions towards the use of QR code in marketing across cultures such as India and Japan by means of SEM analysis. Furthermore, the study attempted to explore moderating role of media, location and on-campaign instructions on the relationship between beliefs and intention using GLM analysis. Culture was influencing belief towards the use of QR codes in marketing and this belief in turn was significantly affecting intention to scan codes. The type of media used and on-campaign instructions were significant moderating variables, whereas consumer location wasn't a significant variable.

\section{LIMITATIONS AND FUTURE RESEARCH}

This study has certain limitations and underlies implications for future research. First of all, the concept of culture in this study was operationalized as respondents' cultural background. This may cause loss of robustness of cross-cultural model, as strong individual differences could exist within such defined cultural group. Second, the study only dealt with behavioral intention rather than actual behavior. Here, the use of behavioral intention as a measure for actual behavior might have led to the loss of some explanatory power of the model. Third, for the sake of parsimony and understanding (as this study area is almost virgin), the model was constrained only to the key constructs of theoretical importance. There could be other significant variables in the context of mobile promotions such as social norms (Shankar and Balasubramanian, 2009), attitude towards advertising in general (Singh and Vij, 2008) on which future studies should focus. Fourth, due to a very short history of QR code marketing, especially in India, consumers' beliefs may still be evolving. Thus, the current cross-sectional design may not be enough to capture that evolution. Hence, a longitudinal study in future may provide more insights into the $\mathrm{QR}$ code marketing from consumers' perspective. Fifth, the student sample both from India and the USA may limit the generalizability of findings. Future research could examine a broader profile of consumers. Kline (2005) recommends that the final model should be tested on a second sample. Due to the size of the sample, such a consideration was not exercised in the study model replication. Therefore, future studies could replicate the model across geographies and ethnic groups. Finally, this study tested moderating effects of media, location and on-campaign instructions on the relationship between beliefs and behavioral intentions towards QR code marketing promotions. Future studies may examine other possible moderators such as code placement and design, incentives offered for code scan, privacy issues etc.

\section{REFERENCES}

Al-Juhiam, O.M. (2008). An empirical investigation of the cultural impact on consumer perception and attitude towards advertising. University of Huddersfield Paper Series. Retrieved October 15, 2012, from http://eprints. hud.ac.uk/4995/1/ojuhaimfinalthesis.pdf

Bamba, F., \& Barnes, S. (2006). Evaluating consumer permission in SMS advertising. In Sprouts: Working papers on information systems. Retrieved August 16, 2010, from http://sprouts.aisnet.org/476/1/Mobile_ Enterprise_2_2.pdf.

Bamoriya, H., \& Singh, R. (2012). SMS Advertising in India: Is TAM a robust model for explaining intention. Organizations and Markets in Emerging Economies, 3(1), 89-101.

Bisel, J. (2011). Mobile marketing and QR codes. Hudson Valley Business Journal, 22(37), 21.

Cheung, G.S.C., \& Li, L.K.W. (2009). The perceptions and attitudes towards SMS advertising in Hong Kong. Retrieved May 07, 2012, from http://libproject.hkbu.edu. hk/trsimage/hp/07013930.pdf.

Daniells, K. (2011). The rise of QR codes. Retrieved November 23, 2012, from http://www.digitalbuzzblog.com/ infographic-the-rise-of-qr-codes/. 
Durvasula, S., \& Lysonski, S. (2013). Consumer decision making styles in retailing: Evolution of mindsets and psychological impacts. Journal of Consumer Marketing, 30(1), 75-87. DOI: 10.1108/07363761311290858.

Hanafizadeh, P., \& Behboudi, M. (2012). Online advertising and promotion: Modern technologies for marketing. Hershey, PA: Business Science Reference.

Hofstede, G. H., Hofstede, G. J., \& Minkov, M. (2010). Cultures and organizations: Software of the mind: intercultural cooperation and its importance for survival. New York: McGraw-Hill.

Karson, E., McCloy, S., \& Bonner, G. (2006). An examination of consumers' attitudes and beliefs towards web site advertising. Journal of Current Issues and Research in Advertising, 28(2), 77-91. DOI: 10.1080/10641734.2006.10505200.

Kiousis, S. (2001). Public trust or mistrust? Perceptions of media credibility in the information age. Mass Communication \& Society, 4(4), 381-403.

Kline, R.B. (2005). Principles and practice of structural equation modeling. New York: Guilford Press.

Ko, H., Cho, C.H., \& Roberts, M.S. (2005). Internet uses and gratifications: A structural equation model of Interactive advertising. Journal of Advertising, 35(2), 57-70. DOI: $10.1080 / 00913367.2005 .10639191$.

La Ferle, C., Edwards, S., \& Lee, W. (2008). Culture, attitudes, and media patterns in China, Taiwan, and the U.S.: Balancing standardization and localization decisions. Journal of Global Marketing, 21(3), 191-205. DOI: 10.1080/0891176080215201.

Mafe', C.R., Sanz Blas, S.S., \& Tavera-Mesıas, J.F. (2010). A comparative study of mobile messaging services acceptance to participate in television programmes. Journal of Service Management, 21(1), 69-102. DOI: $10.1108 / 09564231011025128$.

Mojsa, M., \& Rettie, R. (2003). Attitudes to Internet Advertising: A Cross-cultural Comparison. In Kingston Business School Paper Series. Retrieved October 15, 2012, from http://eprints.kingston.ac.uk/6350/1/RettieR-6350.pdf.

Mooij, M. (2011). Consumer behavior and culture: Consequences for global marketing and advertising. Thousand Oaks, CA: SAGE Publications.

Okazaki, S., Li, H., \& Hirose, M. (2012). Benchmarking the use of QR code in mobile promotion. Journal of Advertising Research, 52(1), 102-117. DOI: 10.2501/ JAR-52-1-102-117.
Patnaik, U.C., \& Patnaik, A.S.C. (2005). Effectiveness of advertising. New Delhi: Sonali Publications.

Podfigurny, R. (2011). Enhancing your marketing with QR codes \& smart-phone technology. Business Journal, 25(37), 15.

Probst, A. (2012). The expectations of quick response (QR) codes in print media: An empirical data research anthology. UW-L Journal of Undergraduate Research. Retrieved November 16, 2012, from http://www.uwlax.edu/urc/ JUR-online/PDF/2012/probst.ali.pdf.

Shankar, V., \& Balasubramanian, S. (2009). Mobile marketing: A synthesis and prognosis. Journal of Interactive Marketing, 23(2), 118-129. DOI: 10.1016/j.intmar.2009.02.002.

Singh, R., \& Vij, S. (2008). Public attitude toward advertising: An empirical study of Northern India. ICFAI Journal of Marketing Management, 7(1), 49-66.

Tolliver-Walker, H. (2011). Making best use of QR codes: Gleaning lessons from the latest data. The Seybold Report, 11(23), 2-7.

Tsang-Sing, C., Geng, C., \& Geng, C. (2004). Consumer attitudes toward marketing in a transitional economy: A replication and extension. Journal of Consumer Marketing, 21(1), 10-26. DOI: 10.1108/07363760410513932.

Usman, M., Saqib, I., Hussain, F., \& Qureshi, T. (2010). General attitude towards advertising: Cultural influence in Pakistan. International Journal of Marketing Studies, 2(2), 124-133.

Wang, Y., \& Sun, S. (2010a). Modeling online advertising: A cross-cultural comparison between China and Romania. Journal of Marketing Communications, 16(5), 271-285. DOI: 10.1080/13527260902884904.

Wang, Y., \& Sun, S. (2010b). Assessing beliefs, attitudes, and behavioral responses toward online advertising in three countries. International Business Review, 19(4), 333-344. DOI: 10.1016/j.ibusrev.2010.01.004.

Wu, J.H., \& Wang, S.C. (2005). What drives mobile commerce? An empirical evaluation of the revised technology acceptance model. Information and Management, 42(5), 719-729. DOI: 10.1016/j.im.2004.07.001. 


\section{PRIMENA QR MARKETING STRATEGIJE}

\section{NA PRIMERU INDIJE I JAPANA}

\section{Rezime:}

Uprkos sve većoj prisutnosti QR kodova (Strategija brzog odgovora) u oblasti marketinga, mnogi kritičari su zabrinuti za njegovu uspešnu integraciju u koncept marketing miksa. Razlog za to jeste nedovoljno poznavanje stavova i namera potrošača kada je reč o upotrebi QR kodova. Ogromne razlike u stopi izloženosti i usvanju QR kodova među različitim kulturama još više se negativno odražavaju na primenu QR kodova u oblasti marketinga. Ova studija ima za cilj da ispita stavove i namere potrošača kada je reč o upotrebi QR kodova u marketingu kod različitih kultura, prventstveno Japana i Indije. Takođe, ovaj rad ima za cilj da ispita kako odabrane varijable utiču na odnos između stavova i namera. Korišćen je scenario zasnovan na eksperimentalnom dizajnu i analizirani su podaci korišćenjem tehnika Modelovanja strukturalnim jednačinama i Opštih linearnih modela. Dobijeni nalazi ukazuju na to da postoji pozitivan odnos između kulture i stavova kao i između stavova i namera korisnika. Takođe, utvrđeno je da mediji i prisustvo/odsustvo instrukcija u okviru marketinških kampanja u velikoj meri utiču na odnos između stavova i namera korisnika. Na kraju, oslanjajući se na ključne nalaze, ova studija nudi korisne informacije i gledišta vezana za dinamičku prirodu QR kodova u oblasti marketinga kao i korisne naznake za marketinške kompanije.

\section{Ključne reči:}

oglašavanje, kultura, mobilni marketing,

QR kod (strategija brzog odgovora).

Received: February 13th, 2014. Correction: September 1st, 2014. Accepted: September 2nd, 2014. 